\title{
The Role of Government Policies and Strategies Behind the Shrinking Urban Core in an Expanding City Region: The Case of Izmir
}

\author{
GÜLDEM ÖZATAĞAN* \& AYDA ERAYDIN** \\ *Department of City and Regional Planning, Faculty of Architecture, Izmir Institute of Technology, Gulbahce \\ Campus, Urla, Izmir, Turkey, ${ }^{* *}$ Department of City and Regional Planning, Faculty of Architecture, Middle \\ East Technical University, Çankaya, Ankara, Turkey
}

(Received July 2012; accepted December 2012)

\begin{abstract}
Over the last few decades, the term urban shrinkage has come to be accepted as a valid concept in international academic circles, and has gradually gained importance, with its causes the subject of well-documented discussion. While previous discussions of urban shrinkage have directed attention to cities shrinking as a whole, recent research started to recognize the case of shrinkage in growing cities and regions. As such, recent discussions of urban shrinkage indicate that patterns of shrinkage vary considerably from city to city, and from sub-region to sub-region, with the importance of local dynamics in responding to changing economic pressures given much consideration. Recent studies have tended to disregard the role of government policies and strategies put in place to facilitate the adaptation of the urban economies to the new conditions. Taking Izmir as an example, being a fast-growing metropolitan region in Turkey, this paper presents evidence of government policies and strategies aimed at enhancing the development of peripheral areas that have led to shrinkage of the metropolitan core. This paper focuses on this experience and discusses its implications.
\end{abstract}

\section{Introduction}

Over the last few decades the problem of urban shrinkage, referring to a process of population loss in a densely populated urban area (Pallagst et al., 2009), has received increasing attention in the literature. While its causes have been documented in a large body of literature with reference to demographic change, economic transformation and suburbanization, recent discussions have been from the perspective of globalization, which is usually associated with a declining economy and a deterioration of urban areas due to a loss of

Correspondence Address: Güldem Özatağan, Department of City and Regional Planning, Faculty of Architecture, Izmir Institute of Technology, Gulbahce Campus, Urla, Izmir, Turkey. Email: guldemozatagan@iyte.edu.tr 
competitiveness. It is argued that the global reorganization of production has been the major underlying cause of shrinkage in many industrial cities, leaving them in the position of being unable to find a niche in the current competitive global economy (see also Audirac et al., 2012; Martinez-Fernandez et al., 2012a, p. 214, 2012b).

Accounts of urban shrinkage to date have underlined that shrinkage may take a variety of forms, and that the processes behind it vary considerably (Cunningham-Sabot \& Fol, 2007; Pallagst, 2008). Grossmann et al. (2008, p. 94), among others, claim that city shrinkage occurs not only in regions experiencing population loss as a whole, but also in growing regions or metropolitan areas, with Rieniets $(2005$, p. 6) pointing out that in most cases shrinking cities are embedded in growing regions, where population loss from the inner cities is accompanied by peripheral sprawl. Urban shrinkage in certain parts of cities, especially core areas in growing metropolitan regions, has started to stimulate discussion but its dynamics are yet to become a well-studied issue.

Moreover, the question of how government policies and strategies contribute to urban shrinkage has to date attracted little interest in discussions of urban shrinkage. Although empirical studies have implicitly dealt with how "going for growth" strategies of governments have contributed to the process of urban shrinkage (Haussermann \& Siebel, 1987; Wiechmann, 2008; Audirac, 2009; Hollander et al., 2009), how government strategies to manage growth and facilitate the adaptation of local economies to the new conditions may result in urban shrinkage in metropolitan regions is a phenomenon that has yet to be studied. A few studies have attempted to address the role of government policies in urban shrinkage, including that of Stanley (2009), who, while evaluating the role of local policies in shaping the process of sprawl and shrinkage, concluded that urban shrinkage was triggered by local policies that encouraged real estate investors to invest more. Similarly, Gordon (2008) has emphasized that the urban shrinkage experienced in St. Louis was the outcome of policies that had been implemented in the city's recent past, while Sousa (2010) has discussed the role of urban planning and policies in the shrinkage of Portuguese cities.

This paper focuses on the process of urban shrinkage in growing metropolitan areas, and discusses how government policies and strategies for managing urban growth can actually contribute to urban shrinkage. An examination will be made of the risks involved in conceptualizing urban shrinkage as a failure of cities to adapt to the global competitive economy, with emphasis on the need to take into account the dynamics of shrinkage in growing metropolitan areas and of the role played by government policies and projects in the emergence of shrinkage. Taking Izmir as an example, being an expanding city region in Turkey that has witnessed shrinkage of its urban core accompanied by rapid metropolitan expansion, the intention is to discuss the ways in which government policies and strategies have led to the shrinkage of the core of this metropolitan region.

The first part of the paper offers an overview of the existing literature on shrinking cities, presenting all aspects of the debate on the relationship between government policies and urban shrinkage. The second part of the paper focuses on the specific case of Izmir, and evaluates the onset of urban shrinkage in a fast-growing metropolitan region. This is followed by an evaluation of government policies and strategies that have contributed to this process. Finally, we conclude with a summary of findings, emphasizing a need to take into account the influence of public policies and strategies when attempting to understand the processes of urban shrinkage. 


\section{Theoretical Framework on Shrinking Cities}

After years of study of growth and growing regions, scholars of urban planning have accepted that population decline and urban shrinkage have become a normal aspect of urban development (Bernt, 2009). Over a quarter of world metropolises witnessed population decline in the 1990s, and despite urbanization trends, these population losses are expected to continue (Oswalt \& Rieniets, 2006). Oswalt and Rieniets (2007) indicated that in the last 35 years, 370 cities with a population of 100,000 or more have lost at least $10 \%$ of their population, particularly in Europe; and Turok and Mykhnenko (2007, pp. 168-169) found that at the end of the 1990s there were more shrinking than growing cities in Europe. According to the Urban Audit (EU, 2007), out of 220 smalland medium-sized cities in Europe, 57\% lost population during the 1996-2001 period, and the European Commission (2007) estimates that by 2020 population decline will have been experienced all over Europe, and that in-migration will be unable to compensate for the losses after that year. The situation is much the same in developing countries, with UN-HABITAT (2008) reporting that out of 1408 developing country cities, 143 have experienced population losses in the 1990-2000 period.

What are the main factors causing urban shrinkage? General consensus in previous literature is that demographic change is one of the major causes, and shrinking cities have been widely studied in this regard, with a substantial number of studies conducted in Europe where the fall in birth rates has been substantial (Wiechmann, 2008). Especially in several cities of Central and Eastern Europe (CEE), a sharp decrease in fertility rate has occurred alongside post-socialist transformation processes (Bontje, 2004), and the simultaneous interplay has led to a severe shrinkage phenomenon (Müller \& Siedentop, 2004; Boren \& Gentile, 2007; Buzar et al., 2007; Haase et al., 2007; Steinfuhrer \& Haase, 2007).

Second, the loss of a competitive economic structure and problems of the local economy in adapting to the new economic conditions defined by globalization have been identified as a key driver of urban shrinkage. Economic decline in old industrialized cities, particularly in the cases of Glasgow, Liverpool and Manchester in Europe (Couch, 2004; Couch et al., 2005; Grant, 2006; Kidd, 2006; Ferrari \& Roberts, 2004), and in Detroit, Pittsburg, Cleveland and Youngstown in the US (Fishman, 2000; Beauregard, 2003, 2006; Booza \& Metzger, 2004; Pallagst, 2009) are just some of the examples referred in the literature. In such cities, urban shrinkage is characterized by job and population loss, disinvestment and a lack of economic competitiveness. It has been argued that while globalization encouraged the growth of competitive and innovative metropolitan areas (Saxenian, 1991; Fisher et al., 2001; Simmie, 2001), global cities (Sassen, 2001) and city regions (Dieleman \& Faludi, 1998; Brenner, 2000; Hall, 2001; Scott, 2001a, 2001b; Eraydin et al., 2008b), the failure of other cities to adapt to the new conditions imposed by globalization led to a subsequent loss of competitive advantage. In particular, CEE countries have experienced the transformation process imposed by the new global economic system more radically. Research has shown clearly how the failure of Leipzig in former East Germany and Ivanovo in Russia to adapt to the transformation process brought about by globalization led them to lose their competitive advantage, and subsequently they experienced dramatic shrinkage (Bontje, 2004; Beyer, 2005; Kil, 2005; Treivish, 2006). Frey (2005), on the other hand, has shown that after the dot.com crisis of the 2000s, urban shrinkage became an issue for cities such as San Jose, San Francisco and Boston, where sectors of the new economy had agglomerated. Similarly, Pallagst (2009) has shown that the brain 
drain from the Silicon Valley in San Jose during the 2000s has resulted in a significant increase in the number of vacant offices and housing stock.

Several growing city regions have also experienced shrinkage in their core areas, one of the main reasons for such a trend being suburbanization. In shrinking cities or city regions, changing housing preferences and the quality of the social amenities provided in the inner cities are very significant. Evidence of this can be found mainly in US cities, where urban shrinkage has often occurred in a doughnut pattern, with the city centre becoming hollow as the population moves out of the metropolitan core and/or inner suburbs to the outer suburbs in search of affordable housing (Booth, 1987; Fishman, 1987; Friedrichs, 1993; Metzger, 2000; Gallagher, 2004; Pallagst \& Wiechmann, 2005). Recently, the innerring suburbs of many US metropolitan regions have witnessed suburban shrinkage (Albecker, 2011; Audirac et al., 2012). In Europe, Glasgow and fast-growing regions in the South of France (Marseille, Avignon, Toulon and Perpignan) (Puentes \& Warren, 2006; Cunningham-Sabot \& Fol, 2009) are some examples of urban shrinkage within urban areas that are growing as a whole, with peripheral settlements growing at the expense of the urban core.

Urban shrinkage has not been confined only to metropolitan areas, as recent evidence indicates it can also be observed in larger urban zones (functional urban regions defined by commuting patterns), including suburban areas. According to the Urban Audit, out of 98 large urban zones in Europe, 54\% shrank in the 1996-2001 period (EU, 2007); however, shrinkage issues in such urban regions cannot be simply interpreted as a result of suburbanization and urban sprawl (see also Wiechmann \& Pallagst, 2012). As Hutton (2008, p. 2) points out, suburban areas are not merely homogeneous residuals of metropolitan centres, but rather have been shaped, among other factors, by the locational tendencies of economic activities, particularly of manufacturing and services, and now contain an increasing share of the population and employment market of city regions. The spatial configuration of these former metropolitan areas has been a result of urban economic restructuring, characterized by the redistribution of economic activities at a metropolitan scale to respond to the new dynamics of global restructuring. In such cases, the shrinkage that can be observed in different parts of the city region has been triggered by the placement of new activities in new spaces, along with the relocation of the existing activities from the existing sites. In these types of city regions, suburbanization, sprawl and shrinkage are simultaneously observed. Evidence shows that such dynamics are also at play in cities, especially in CEE countries, where the population is not reproducing itself (Müller \& Siedentop, 2004; Tammaru et al., 2004; Nuissl \& Rink, 2005; Rieniets, 2005; Haase et al., 2007), and in many cases these processes have been driven by supply supported by governmental incentives, funding schemes and transfers (Couch et al., 2005; Nuissl \& Rink, 2005).

All of the above evidence indicates that the processes causing urban shrinkage vary considerably depending on national, regional and local contexts (Cunningham-Sabot \& Fol, 2007; Pallagst, 2008); however, as Bernt (2009) underlines, the question of how these differences in patterns of shrinkage are shaped by local dynamics, particularly government policies and strategies, is yet to be answered.

\section{Shrinkage and the Importance of Government Policies and Strategies}

Although the role played by government policies and strategies in the onset of urban shrinkage has to date not been an explicitly studied issue, a number of empirical studies 
have implicitly criticized the "going for growth" strategies applied by governments for intensifying the shrinkage phenomenon (Wiechmann, 2008; Audirac, 2009; Hollander et al., 2009). These strategies are generally introduced by local and/or national governments to overcome some of the negative consequences of urban shrinkage. For example Wiechmann's (2008) research identifies a number of strategies applied in Dresden since the 1990s that have contributed negatively to the shrinkage phenomenon. These include investment activities such as the construction of large-scale retail and hospitality projects, new commercial zones and office locations, new housing units and the establishment of a highly competitive high-tech industry. Two trends appear to be important here. The first is the spatial focus of these investment activities, which tend to be on the outskirts of the city; and the second is that they were either influenced by national investment incentives or were established with state support with the intention of turning around a downgrading urban economic structure.

Grossmann et al. (2008, p. 83) indicate that the overambitious building and refurbishment activities sponsored by the state during the 1990s contributed significantly to the evolving housing vacancies in East Germany; while Nuissl and Rink (2005) note that urban sprawl in stagnating or declining urban regions is frequently shaped by government and local policies rather than market forces. For example, federal housing and tax policies, the most famous of which is a subsidy for the acquisition of property by private households, have provided strong incentives for urban sprawl, triggering the phenomenon of urban shrinkage. Similarly, Bernt (2009) emphasizes that despite the increase in housing vacancies in East Germany, tax exemption and construction activities supported by state subventions have caused a significant upswing in the number of vacant properties.

Investigating the process of urban sprawl in the two shrinking cities of Liverpool and Leipzig, Couch et al. (2005) claim that the process has not been shaped by market forces, but by the laws and regulations enacted by local governments. Gordon (2008) argues that the decline of St. Louis has not been simply the consequence of a free market, but the web of local, state and federal policies that allowed race and class segregation. He specifies that a set of exclusionary land-use policies and practices, weak affordable housing policies and a lack of control of sprawl had the effect of compounding economic decline and a more uneven distribution of its consequences. Gordon goes on the highlight in particular the "redlining" of federal housing assistance, by which realtors could only sell houses to minority populations inside the red line under threat of losing their licenses if they did otherwise; restrictive municipal zoning policies that single out lower-class citizens; public housing policies that forced minority residents out of the city and urban renewal policies that had the effect of razing minority neighbourhoods for a higher (often commercial) use.

The implication of all the above studies is that local and state government policies and strategies are increasingly contributing to the shrinking of cities. It has been highlighted that in many stagnating or shrinking urban regions, strategies introduced by local and/or national governments to overcome urban shrinkage or its negative consequences have been counterproductive, having contributed to the problem rather than abrogating it. Despite all of the evidence, the role of government policies and strategies in urban shrinkage has not emerged as an explicitly studied phenomenon. The rest of the paper will investigate this issue in detail with reference to Izmir - a fast-growing city region in Turkey that is striving to adapt to the competitive global economy. 


\section{Exploring Shrinkage in a City Region that Strives to Adapt to the Competitive Global Economy}

Izmir is one of many city regions in Turkey that had experienced substantial changes in spatial organization and rapid growth of the peripheral area, accompanied by the shrinkage of the urban core. The change in the urban dynamics and redistribution of population are highly connected to the economic structure of the region, which has undergone substantial transformation in the last three decades in attempting to adapt to the new conditions imposed by the global economic system. However, in the Izmir case, besides local dynamics, policies and strategies of national and local governments have also been decisive in the changing spatial organization of the city region.

This section of the paper aims to explain both the characteristics of the pattern of shrinkage together with its causes, and to explore the effect of government policies and projects in the onset of a shrinking metropolitan core. The Izmir case study aims to show that shrinkage is not only an outcome of local dynamics, but also of government policies and projects that fail to grasp the changing dynamics of the local economy in response to the global conditions. In fact, the Izmir case is just one of many examples in Turkey in which a city has shrunk as a result of government policies to increase the competitiveness of the city region to overcome the problems faced during the process of adapting to the new conditions.

\section{Shrinking Urban Core in an Expanding City Region}

Izmir is a growing metropolitan region, having increased from a population of 2.8 million in 1990 to 3.6 million in 2000, and further to 4.5 million in 2008, indicating a population boom in the most recent decade. What is more important, however, is the pattern of population growth, which indicates a clear shift from the urban core towards settlements in its periphery. Table 1 presents population figures for the metropolitan core, inner periphery, outer periphery, Izmir city and city region in 1990, 2000 and 2008; and also the annual population changes of the above categories in different periods. The contrast between the population increase in the metropolitan periphery and the decline in the metropolitan core is clearly apparent in the presented data. Absolute declines of population between 1990 and 2000 are confined to the metropolitan core, whereas all significant growth is in the inner and outer periphery.

Table 1. Population change in different periods

\begin{tabular}{|c|c|c|c|c|c|c|}
\hline & \multicolumn{3}{|c|}{ Urban population } & \multicolumn{3}{|c|}{$\%$ Annual Change } \\
\hline & 1990 & 2000 & 2008 & $1990-2000$ & $2000-2008$ & $1990-2008$ \\
\hline Metropolitan core & 475,800 & 401,704 & 411,112 & -1.56 & 0.29 & -0.76 \\
\hline Inner periphery & 890,714 & $1,450,902$ & $2,261,014$ & 6.29 & 6.98 & 8.55 \\
\hline Outer periphery & 377,402 & 500,404 & 778,411 & 3.26 & 6.94 & 5.90 \\
\hline Distant periphery & 700,782 & 879,362 & $1,051,327$ & 2.55 & 2.44 & 2.78 \\
\hline Izmir City & $2,134,816$ & $2,732,669$ & $3,450,537$ & 2.80 & 3.28 & 3.2 \\
\hline Izmir City Region & $2,835,598$ & $3,612,031$ & $4,501,864$ & 2.74 & 3.08 & 3.26 \\
\hline
\end{tabular}

Note Metropolitan core + Inner periphery = Izmir Metropolitan Area; Izmir Metropolitan Area + Outer periphery = Izmir City; Izmir City + Distant Periphery = Izmir City Region.

Source: Authors' elaboration based on TurkStat, Census of Population, 1990, 2000. 
Shrinkage in the urban core, along with the growth of employment in the peripheral areas, especially in the inner periphery of the metropolitan area, is also evident from the employment figures from 1990 to 2000 . Table 2 shows that the employment in the Izmir City Region as a whole expanded during the 1990s, and that most of this expansion took place in the manufacturing (49\%) and services (74\%) sectors in the inner periphery. In contrast, a number of settlements in the outer periphery experienced job losses in the 1990s, especially in the agricultural sector. This loss was compensated for by gains in manufacturing employment in the specialized growth centres, causing employment in the outer periphery to grow by $6.67 \%$ between 1990 and 2000 .

Another characteristic of the transformation of the Izmir City Region is job losses (45\%) and shrinkage in the metropolitan core. Table 2 shows that the metropolitan core lost not only agriculture-related employment, but also manufacturing between 1990 and 2000 as industrial activities spread to the peripheral areas. While employment in the services sector has on the whole risen in Izmir, it has moved out of the metropolitan core to become concentrated in the inner periphery, with services sector employment in the inner periphery increasing by 74\% between 1990 and 2000, and declining by $41 \%$ in the metropolitan core.

The figures on population and different activities in different years indicate a shift of population and employment growth from the metropolitan core to peripheral areas, with significant impact on the metropolitan core of the region. Figure 1 shows this change from 1990 to 2000, during which employment growth moved from the metropolitan area to its periphery, and a growth in the number of peripheral settlements began. By the 2000s, a series of major new centres of growth had appeared at the outskirts of the

Table 2. Sectoral distribution of employment in Izmir, 1990-2000

\begin{tabular}{lcccccc}
\hline & & Total employment & Agriculture & Mining & Manufacturing & Services \\
\hline Metropolitan core & 1990 & 221,025 & 8636 & 116 & 61,006 & 147,012 \\
& 2000 & 120,655 & 721 & 90 & 33,340 & 86,216 \\
& $\%$ Change & -45.41 & -91.65 & -22.41 & -45.35 & -41.35 \\
Inner periphery & 1990 & 351,065 & 9129 & 398 & 107,785 & 229,290 \\
& 2000 & 565,390 & 4824 & 592 & 160,800 & 398,507 \\
& $\%$ Change & 61.05 & -47.16 & 48.74 & 49.19 & 73.80 \\
Outer periphery & 1990 & 141,926 & 31,336 & 315 & 24,053 & 83,926 \\
& 2000 & 151,388 & 18,815 & 627 & 31,178 & 100,604 \\
& $\%$ Change & 6.67 & -39.96 & 99.05 & 29.62 & 19.87 \\
Distant periphery & 1990 & 181,622 & 37,880 & 473 & 30,856 & 109,915 \\
& 2000 & 185,151 & 22,078 & 751 & 32,962 & 128,858 \\
& $\%$ Change & 1.94 & -41.72 & 58.77 & 6.83 & 17.23 \\
Izmir City & 1990 & 714,016 & 49,101 & 829 & 192,844 & 460,228 \\
& 2000 & 837,433 & 24,360 & 1309 & 225,318 & 585,327 \\
Izmir City Region & \% Change & 17.28 & -50.39 & 57.90 & 16.84 & 27.18 \\
& 1990 & 951,611 & 90,745 & 1352 & 240,431 & 604,903 \\
& 2000 & $1,087,336$ & 49,213 & 2158 & 279,414 & 754,693 \\
& $\%$ Change & 14.26 & -45.77 & 59.62 & 16.21 & 24.76 \\
\hline
\end{tabular}

Note: Metropolitan core + Inner periphery = Izmir Metropolitan Area; Izmir Metropolitan Area + Outer periphery = Izmir City; Izmir City + Distant Periphery = Izmir City Region.

a TurkStat does not provide employment figures after 2000.

Source: authors' elaboration based on TurkStat, Census of Population, 1990, 2000. 


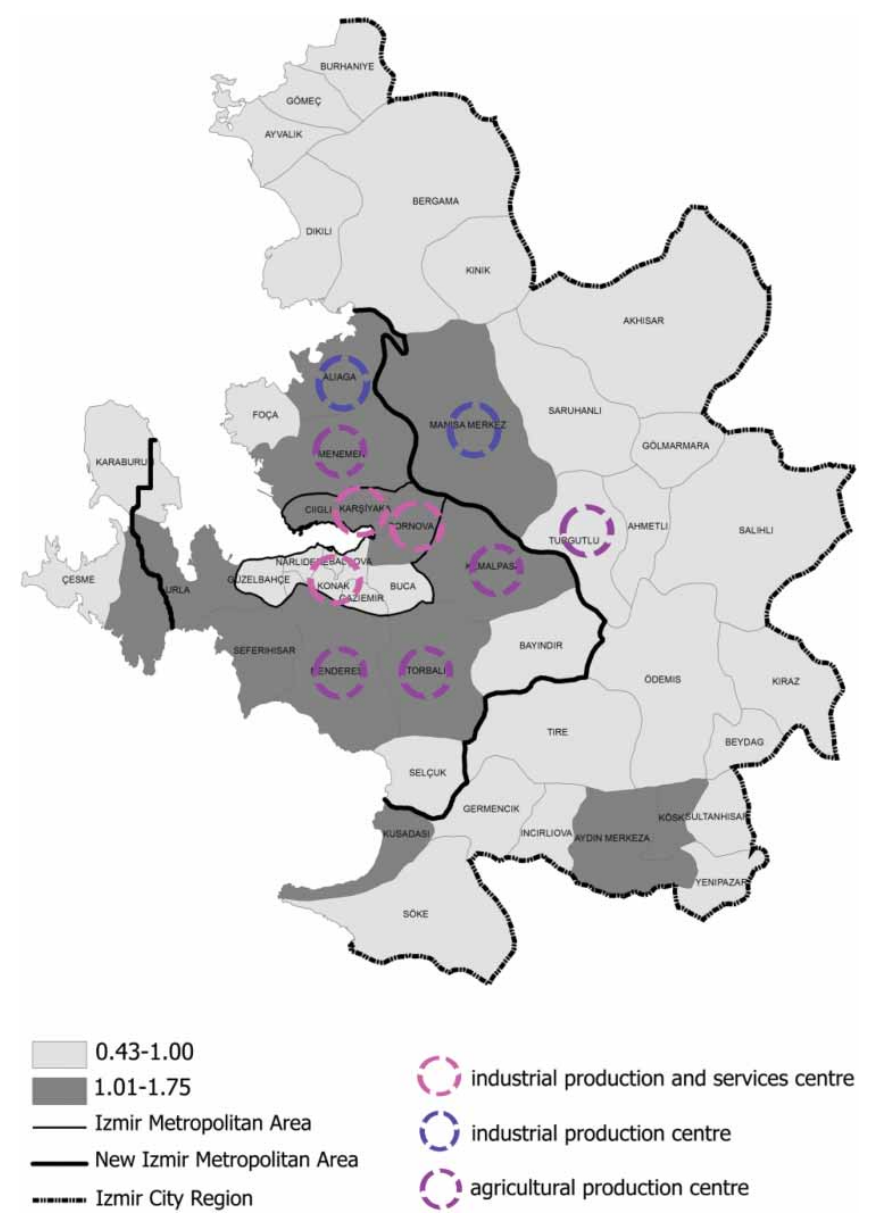

Figure 1. Redistribution of employment in Izmir City Region and functional specialisations (1990-2000).

Notes: (1) Redistribution index $(\mathrm{RI})=(\operatorname{Eit}(1) / \operatorname{Et}(1)) /(\operatorname{Eit}(0) / \operatorname{Et}(0))$; Ei: employment of the settlement $i, E$ : Employment of the Izmir Urban Region, $t(0)$ beginning year and $t(1)$ final year. RI greater than 1 implies that the settlement gains employment in the process of redistribution; whereas RI smaller than 1 implies that the settlement is losing population. Settlements in Izmir City Region with a sectoral specialization index greater than 1. (2) The Izmir Metropolitan Area identifies an official boundary defined in 1981 by the Municipality of Izmir as part of the Izmir province. The New Izmir Metropolitan Area was defined in 2004 and refers to the extended boundary of the Izmir Metropolitan Area in a way to cover all the settlements within a $50 \mathrm{~km}$ radius. The aim was to overcome a number of problems - in the provision of public services and the coherence of planscaused by the continuous increase in the number of newly emerging settlements and municipalities in the periphery of the Izmir Metropolitan Area throughout the 1990s (Eraydin et al., 2008a, p. 2297). While the provincial boundary of Izmir identifies a larger area than the New Izmir Metropolitan Area, as is the case with many rapidly growing regions in the world, it does not represent fully the increasing interconnectivity and functional integration of the metropolitan area with the settlements in itperiphery, which required the identification of the Izmir City Region for research purposes. 
metropolitan area, which now constitute some of the most dynamic and rapidly expanding foci of the spatial economy of Izmir. Within the region's peripheral settlements we can identify, as important outcomes of restructuring, new spatial divisions of economic activity, notably the growth of settlements specialized in different economic activities thanks to the spillover effects from the metropolitan core (Figure 1). The result has been the evolution of Izmir from a metropolitan area with a large hinterland into a city region in which the metropolitan area has become functionally integrated with a number of specialized settlements in its periphery (Eraydin et al., 2008b, p. 151). Obviously, as urban growth has moved outwards from core to peripheral areas, it is pre-eminently the metropolitan core that has suffered the most, with signs of urban shrinkage.

\section{Changes in the Economy of the Izmir City Region}

The changing patterns of population distribution and employment in Izmir are associated with the changing economic structure of the city, which can be summarized under three headings: restructuring of the economy, the changing composition of the manufacturing sector and the growth of new types of services.

\section{Restructuring of the Economy}

Izmir has been an important centre of manufacturing, trade and services in Turkey since the beginning of the Republican period, and achieved high rates of economic growth from 1960 to 1980 under the economic policies to promote import substitution. Since the beginning of 1980s, Izmir has been affected considerably by the liberalization of economic policies and attempts to initiate export-oriented growth. The changing economic priorities deeply affected Izmir's economy, which are inscribed within a number of changes in the structure of Izmir's labour force.

Table 3 shows that the share of manufacturing employment in Izmir grew over the 1990s, but then fell slightly after 2002, although not to 1992 figures, and that between 1992 and 2008, services sector employment increased considerably. Within the services sector, the shares of finance, real estate and business services have witnessed consistent growth since the 1990s, while most other service industries have experienced a decline. The share of social and personal services underwent a consistent decline from 17\% in 1992 to $9 \%$ in 2008, while the share of wholesale and retail trade employment declined from 1992 to 2002, but witnessed a sluggish upturn from 2002 to 2008. Despite the rising importance of finance, real estate and business services, the services sector in Izmir continues to be led by the wholesale and retail trade. These figures clearly indicate that while Izmir continues to be an industrial economy, it tertiarized from 1992 to 2000, reflecting its international gateway functions as well as its rising strength in service provision.

\section{Restructuring of Manufacturing from Low-technology Industries to Medium- to High-technology Industries}

Manufacturing remains one of the pillars of Izmir's economy, employing almost one-third of the working population; however, a substantial change was witnessed in employment within the different parts of the sector. Prior to the 1990s, low-technology manufacturing 
Table 3. The changes in the level of employment by sectors

\begin{tabular}{|c|c|c|c|c|c|c|c|c|}
\hline & \multicolumn{3}{|c|}{ Employment } & \multicolumn{3}{|c|}{$\begin{array}{l}\text { Share in total } \\
\text { employment }\end{array}$} & \multirow{2}{*}{$\begin{array}{c}\text { Annual } \\
\text { change } \\
(\%) \\
2002- \\
2008\end{array}$} & \multirow{2}{*}{$\begin{array}{c}1992- \\
2002\end{array}$} \\
\hline & 2008 & 2002 & 1992 & 2008 & 2002 & 1992 & & \\
\hline Manufacturing & 195,987 & 155,995 & 44,090 & 30.68 & 35.24 & 22.11 & -0.76 & 1.31 \\
\hline $\begin{array}{l}\text { Electricity, gas and } \\
\text { water }\end{array}$ & n.a & 4240 & 5476 & n.a & 0.96 & 2.75 & n.a & -0.18 \\
\hline Construction & 44,757 & 13,068 & 8308 & 7.01 & 2.95 & 4.17 & 0.68 & -0.12 \\
\hline $\begin{array}{l}\text { Wholesale and retail } \\
\text { trade }\end{array}$ & 201,124 & 128,521 & 89,393 & 31.49 & 29.03 & 44.82 & 0.41 & -1.58 \\
\hline $\begin{array}{l}\text { Social and personal } \\
\text { services }\end{array}$ & 57,306 & 58,200 & 34,120 & 8.97 & 13.15 & 17.11 & -0.70 & -0.40 \\
\hline $\begin{array}{l}\text { Transport, storage and } \\
\text { communication }\end{array}$ & 53,629 & 36,396 & 5245 & 8.40 & 8.22 & 2.63 & 0.03 & 0.56 \\
\hline $\begin{array}{l}\text { Finance, real estate, } \\
\text { business }\end{array}$ & 65,458 & 41,244 & 10,550 & 10.25 & 9.32 & 5.29 & 0.16 & 0.40 \\
\hline $\begin{array}{l}\text { Other community, } \\
\text { social and personal } \\
\text { service activities }\end{array}$ & 14,119 & 9373 & 5653 & 2.21 & 2.12 & 2.83 & 0.02 & -0.07 \\
\hline
\end{tabular}

Source: Authors' elaboration based on TurkStat, Annual Industry and Service Statistics, 2008; General Census of Manufacturing and Business Local Units, Provinces, 2002, 1992.

employed the most people, but in the following decade their share declined considerably to the benefit of medium-technology manufacturing, and the two came to equilibrium. Employment in medium-low-technology sectors increased 5.7 times from 1992 to 2008 , increasing their share in total manufacturing employment from $21 \%$ to $27 \%$ (Table 4), while employment in the medium-high technology sector increased more than seven times, increasing from $14 \%$ to $23 \%$. These figures suggest that the restructuring of Izmir's economy was not in the form of a hollowing out of the industry, but rather a transformation of the manufacturing sector through the promotion of industrial productivity through technology intensification.

\section{Growth of the New Services Seeking New Locations}

As outlined above, Izmir's economy has been shaped increasingly by the growth of its services sector, with the period from 1990 to 2008 seeing particularly rapid expansion in finance, insurance and real estate services as a result of its characteristics as a gateway. However, the pattern of services growth has witnessed a shift across the metropolitan region. Table 5 provides details of services employment from 1990 to 2000 for the metropolitan core, inner periphery, outer periphery, Izmir City and City Region. It can be seen that many of the former functions of the metropolitan core, including wholesale, retail, social and personal services, have shifted to the inner and outer peripheries, following the decentralization of population and manufacturing. Table 5 also indicates that both the inner and outer peripheries have grown in the provision of finance, insurance and real estate services over the designated period, while the metropolitan core has seen a downturn in this form of employment. 
Table 4. The changing composition of the manufacturing industry

\begin{tabular}{|c|c|c|c|c|c|c|c|c|}
\hline \multirow[t]{2}{*}{ Types of industries ${ }^{\mathrm{a}}$} & \multicolumn{3}{|c|}{ Employment } & \multicolumn{3}{|c|}{ Share in total employment } & \multicolumn{2}{|c|}{ Annual change } \\
\hline & 2008 & 2002 & 1992 & 2008 & 2002 & 1992 & $2002-2008$ & $1992-2002$ \\
\hline Low-tech industries & 99,826 & 99,967 & 28,524 & 50.94 & 64.08 & 64.69 & $-2,19$ & -0.06 \\
\hline Medium-low tech industries & 52,678 & 27,192 & 9289 & 26.88 & 17.43 & 21.07 & 1.57 & -0.36 \\
\hline Medium-high tech industries & 44,483 & 28,836 & 6277 & 22.70 & 18.49 & 14.24 & 0.70 & 0.42 \\
\hline
\end{tabular}

${ }^{a}$ Based on OECD (2003) classification of industries by technological intensity: low-tech industries: manufacturing not classified elsewhere and recycling; wood, paper, printing, publishing; food products, beverages and tobacco; and textiles, textile products, leather and footwear.

Medium-low tech industries: rubber and plastic products; coke, refined petroleum products and nuclear fuel; other non-metallic mineral products; and basic metals and fabricated metal products.

Medium-high tech industries: electrical machinery and apparatus not classified elsewhere; motor vehicles, trailers and semi-trailers; chemicals; railroad equipment and transport equipment not classified elsewhere; and machinery and equipment not classified elsewhere.

Source: Authors' elaboration based on TurkStat, Annual Industry and Service Statistics, 2008; General Census of Manufacturing and Business Local Units, Provinces, 2002, 1992. 
Table 5. Changing spatial distribution of services, 1990-2000

\begin{tabular}{|c|c|c|c|}
\hline & $\begin{array}{l}\text { Wholesale and retail } \\
\text { trade } \\
1990-2000 \% \text { Change }\end{array}$ & $\begin{array}{c}\text { Finance, insurance and real } \\
\text { estate } \\
1990-2000 \% \text { Change }\end{array}$ & $\begin{array}{l}\text { Social and personal } \\
\text { services } \\
\text { 1990-2000\% Change }\end{array}$ \\
\hline Metropolitan core & -29.52 & -37.77 & -47.26 \\
\hline Inner periphery & 84.91 & 76.85 & 89.61 \\
\hline Outer periphery & 31.77 & 35.28 & 21.05 \\
\hline Distant periphery & 28.87 & 35.29 & 18.70 \\
\hline Izmir & 36.74 & 33.02 & 30.13 \\
\hline Izmir City Region & 34.86 & 33.40 & 27.30 \\
\hline
\end{tabular}

Note: Metropolitan core + Inner periphery = Izmir Metropolitan Area; Izmir Metropolitan Area + Outer periphery = Izmir City; Izmir City + Distant Periphery = Izmir City Region.

Source: Authors' elaboration based on TurkStat, Census of Population, 1990, 2000.

These findings suggest that while the inner and outer peripheries remain as the primary focus of manufacturing and services, employment in the metropolitan core is declining to a significant degree. Just as there has been an observable decentralization of manufacturing employment, an analogous decentralization of service functions is also apparent. The economy of the metropolitan core is also declining in terms of employment in the services sector, particularly in social and personal services, and to a lesser extent in business and financial services. It would appear that the decline of manufacturing employment in the metropolitan core was not accompanied by a strong development of employment in the services sector, especially in such producer services as finance, real estate and business, resulting in shrinkage of the metropolitan core.

The economic changes explained above have been accompanied by significant changes in the spatial configuration of economic activity. New projects have been directed towards peripheral areas, and the capital that had been invested in the metropolitan area started to move out to various settlements in the periphery. An evaluation of the issues discussed so far suggests that new specializations and increasing growth in the periphery of the city region has been accompanied by a shrinking inner city, signalling a complex pattern of growth that has decentralized towards a number of settlements in the periphery of the metropolitan area, where different types of economic activity have become concentrated. This has been accompanied by a shrinking metropolitan core in terms of both population and employment, which is something that this fast-growing metropolitan region has been experiencing for the first time in its recent history. The resulting spatial configuration of the Izmir City Region today is one in which processes of growth, concentration, dispersion and shrinkage interplay together, a result not only of local response to pressures of globalization, but also overambitious government policies and strategies to reshape the region's spatial structure with the aim of facilitating the integration of the city region to the global economic system. This shall be the topic of focus in the next part.

\section{The Role of Government Policies and Strategies in the Emergence of Urban Shrinkage in Izmir}

Recent literature has increasingly laid the blame for the intense phenomenon of urban shrinkage on the "going for growth" strategies of governments. Empirical studies of 
shrinking cities around the world have underlined that in many cases the strategies introduced by local and/or national governments have contributed to intensifying shrinkage rather than having the intended effect of abrogating the existing problems. Among such strategies, the most widely mentioned are large-scale retail and competitive industries, new commercial zones and office districts, as well as new residential areas, which most commonly are located in the outskirts of the city. As such, central and/or local governments' housing and tax policies, incentives and subventions that have facilitated urban sprawl in stagnating urban regions are mentioned as factors that triggered urban shrinkage. A few recent studies have gone even further, arguing that urban shrinkage is caused primarily by such policies and strategies rather than by some other factors that are widely mentioned by scholars in the literature (Gordon, 2008; Stanley, 2009).

The public projects or projects supported by governments outlined above have also been significant in the emergence of a shrinking urban core in Izmir, after being introduced and implemented by local and national governments in line with their "growth" and "sprawl" strategies. Since the introduction of export-oriented development policies in Turkey in 1980, the physical inscriptions of the subsequent three decades of growth of in Izmir have been shaped largely by local and central government policies. These have included strategic transport and industrial infrastructure projects and other interventions into the built environment. Here, we can reference the expansion of industrial estates on the periphery of the city region; the network of express highways constructed to facilitate the movement of goods and people throughout the city region; the railway system and housing investments. These elements of Izmir's development landscape provide impressive evidence of Izmir's rapid progression from a metropolitan region to a city region, but have been the major driving force behind the onset of a shrinking metropolitan core. This paper will continue with an evaluation of the ways in which these policies and strategies have played a role in the emergence of urban shrinkage in the Izmir City Region.

\section{Policies Oriented to Change the Structure and Spatial Distribution of Industry: The Emergence of New Specialized Nodes in the Periphery and De-industrialization of the Metropolitan Core}

Just as in other metropolitan areas of Turkey, new industrial zones have emerged, encouraged by the central government incentives as part of a major industrial policy in Izmir, and up until the 1980s various industrial sites and districts were established in the metropolitan area. However, beginning from the 1980s onwards government policies have aimed to facilitate the integration of Izmir into the global system and to help in the restructuring of its industry. The establishment of organized industrial districts has been an important policy tool in this process, and 17 such zones have been established within the Izmir City Region since the 1990s, with an additional three under construction (Figure 2). While the promotion of organized industrial zones has been a central government policy since the 1990s, of particular importance in the case of Izmir were the attempts of some local governments to establish their own industrial districts by seeking financial support from the central government. This resulted in the dispersion of manufacturers of industrial goods and finished products from the metropolitan core to the settlements in the periphery, and encouraged new settlements to take on specializations that were once undertaken in the metropolitan core. In this process, a number of peripheral settlements with rich agricultural land have emerged as agricultural production nodes, while others 


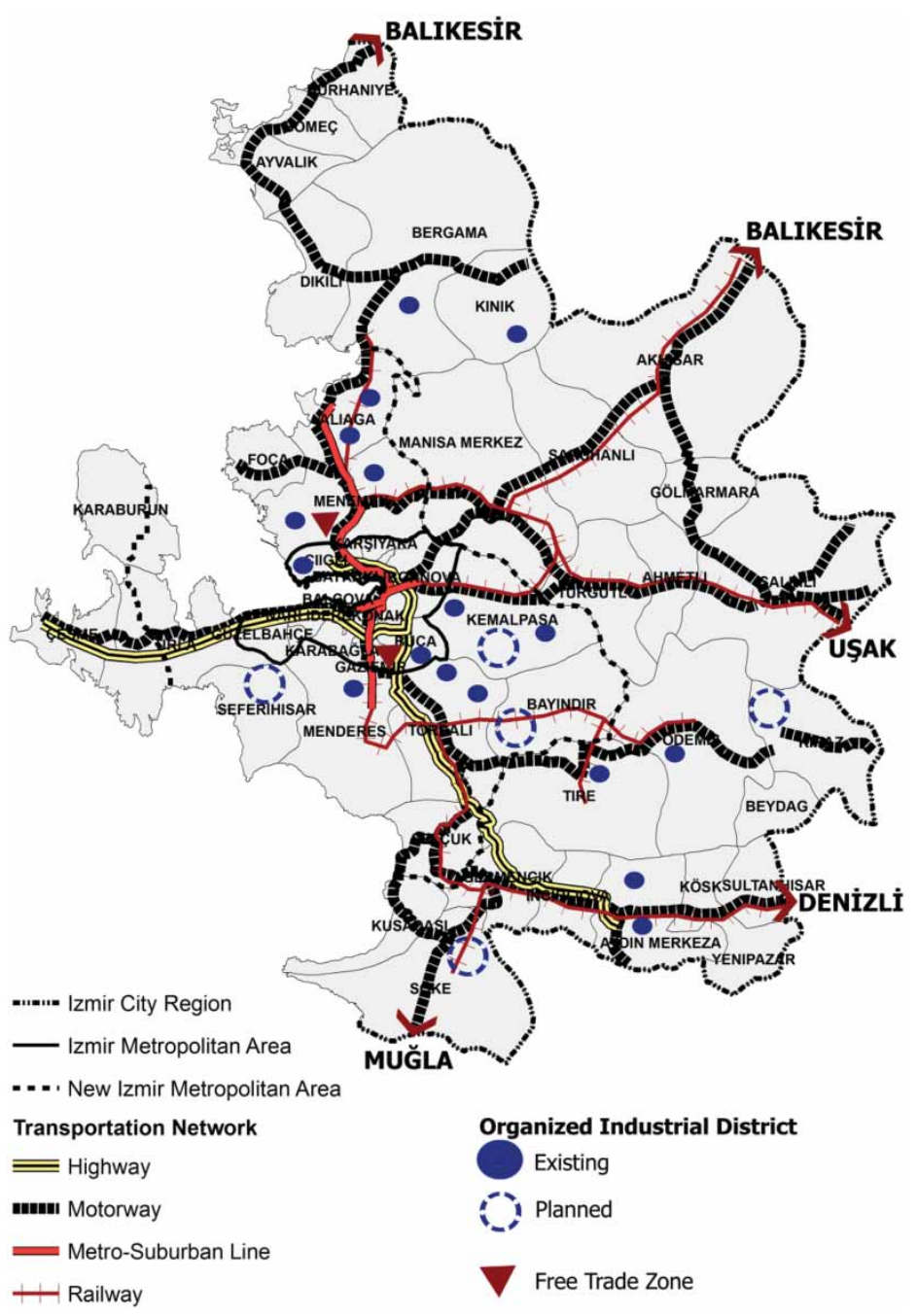

Figure 2. Organized industrial zones and transport routes that influence the distribution of industry and settlement structure.

with different specializations of industrial activity in their past have emerged as manufacturing nodes specialized in different production activities. Two free trade zones were established by the central government in the settlements in the periphery of the metropolitan core: one in the northern part of the Izmir City Region specialized in the trade of leather products, and the other in the eastern part of the region, specialized in the trade of high-tech products, textiles and leather, textile machinery and consumer goods.

The development of organized industrial districts and free trade zones in peripheral settlements allowed the dispersion of industrial goods and finished products from the metropolitan core to settlements in the periphery, and encouraged new settlements to take on some specializations, contributing to the metropolitan core suffering the loss of industrial employment. 
Transport Policies: New Transport Projects to Facilitate the Flow of People among the Settlements that Make-up the Izmir City Region, Contributing to de-Industrialization and Sprawl

Obviously, the emergence of new settlements with new specializations required new transport networks and the renewal of the existing ones (Figure 2). An evaluation of the sectoral distribution of public investment stock in Izmir in 2007 indicates that $52 \%$ of all public investments were made in the transport and communications sector. Of particular significance is the network of expressways constructed to facilitate the movement of goods, services and commuters throughout the Izmir City Region. These include a highway that passes through the agricultural hinterland of the Izmir region, facilitating access to and from the airport and connecting the metropolitan core with various tourism and cultural sites on the south-west coast of Turkey. A further expressway was constructed between the Izmir metropolitan core and the tourism centres and coastal summer houses, which contributed to the transformation of the holiday homes along this route into primary residences, while another was constructed to connect the Izmir port with the manufacturing centres in the east of Izmir. Further transport projects include the construction of a highway through the agricultural production centres in the eastern part of Izmir, connecting the region with Bursa and Istanbul, and the upgrading of the highways connecting Izmir port with the industrial centres to the north and east, and the agricultural centres to the east. A number of motorways that connect the metropolitan core with various settlements on the coast from the north through the south have been upgraded, which has increased the attraction of these settlements as tourism centres and second-home settlements.

Coming to the railway network, a number of existing national railway routes have been upgraded, not only to facilitate the movement of agricultural goods from the eastern hinterland of Izmir to the port, but also to serve as a gateway to the northern, eastern and southern parts of Turkey. Some parts of the existing railway network have been transformed into a high-speed transit system, easing home-to-work commuting. Another railway line extends to the industrial centre in the north, while a further line connects to the agricultural centres in the southeast and to the airport. Finally, the suburban rail system provides a regular service to the major districts in the metropolitan area, further facilitating commuting, and also contributing to the sprawl of the metropolitan area.

\section{Housing Policies}

Obviously, increasing connections between settlements that make up the Izmir City Region and the redistribution of manufacturing activities through the creation of industrial districts are accompanied by housing policies. While housing provision was concentrated in the Izmir metropolitan area until 1980, since that time there has been an increase in the number of housing units in the periphery.

Two major mass-housing acts that were enacted in 1981 and 1984 played a significant role in this process. These were aimed at encouraging the development of state-owned land through the provision of credits to housing cooperatives, ${ }^{1}$ resulting in a boom of housing cooperatives building large-scale mass-housing projects for low- and middle-income groups on the outskirts of cities. Starting in the late-1980s, a significant number of large-scale mass-housing projects for low- and middle-income groups were undertaken by large cooperatives, led either by the Izmir Greater Municipality, district municipalities 
or the Emlak Bank. More than 68,000 houses were constructed prior to 2000 in masshousing projects led by the municipalities, and in the 1990s, $36.42 \%$ of these were constructed in districts making up the inner periphery of the metropolitan area.

Mass-housing projects continued to spring up during the 2000s, but are now taking a different form. First, settlements in the periphery of the Izmir Metropolitan Area have become the location of choice for mass-housing development. Of all mass-housing projects, more than $62 \%$ were constructed in these areas. Second, the Housing Development Agency (HDA) has become the leading actor in housing provision, and has been responsible for implementing mass-housing projects since the 1990s when it was given the authority to develop land, draw up plans at every scale and prepare transformation projects in unauthorized residential areas. Accordingly, the HDA has become the most important actor in housing provision in the 2000s.

Another central government policy that has contributed significantly to the process of sprawl since the 1990s has been the new legal arrangements put in place to encourage large capital holders to invest in urban housing projects. These laws and incentives provided favourable conditions for investors, who are able to avoid the restrictions associated with planning processes (Iş1k, 1996, p. 799). These incentives paved the way for the influx of private large-scale capital to supply large-scale housing projects on the outskirts of the city for middle- and high-income groups who were seeking better living conditions outside the congested and polluted city. As a result, sites offering an alternative and better quality of life have become more widespread since the 1990s, and have given rise to a number of luxurious gated communities far outside the metropolitan area for the affluent, where work and industry and lower-income residences have been decisively excluded (Ayata, 2002). The coastal settlements and the tourism centres along the western and southern coasts have been most popular places for such investments, and have triggered a process of conversion of second homes into primary residences.

The issues raised above offer a clear indication that a number of indirect measures employed by both local and central governments have had an unprecedented shrinkage effect on the urban core in Izmir, although the main motivation behind these policies and strategies has been to facilitate the internationalization and globalization of the city.

\section{Conclusion}

Over the last three decades, the evolution of Izmir has followed a path of continuous growth, both in economic and demographic terms. The internationalization, globalization and growth of the city, starting from the 1980s, have been accompanied by a transformation of its economic and spatial structure. The most significant characteristic of this transformation and the associated spatial reorganization has been the emergence of settlements in the periphery of the metropolitan area with specializations in different economic activities, and their increasing importance in the process of the redistribution of population and employment within the newly emerged Izmir City Region. The findings presented in this paper suggest that the balance of metropolitan growth has shifted to settlements in the inner and outer periphery, and it is here, more than anywhere else, that jobs and population are recuperating on the economic landscape. It is all too apparent that it is the metropolitan core that has suffered the most in this process, with significant losses in all sectors of employment, including manufacturing and services. The metropolitan core has thus started to show signs of urban shrinkage. Hence, an important and unprecedented impact of the transformation of this growing city region since the 1980s has been the urban shrinkage of the metropolitan core. 
Obviously, the picture sketched above is largely different from that painted by the previous literature in terms of the patterns, causes and characteristics of the urban shrinkage being experienced by cities losing population as a whole. The study of urban shrinkage in a fast-growing city region serves as a reminder that urban shrinkage is not limited to cities losing population due to low birth rates, out-migration and a failure to adapt to changing economic conditions. Instead, urban shrinkage has become an emergent characteristic of the process of contemporary urban change and the resulting "urban field" or "city region". In the case of Izmir we have shown that focusing only on suburbanization as the major cause of urban shrinkage is insufficient when attempting to explain why urban shrinkage has become an emerging characteristic of contemporary urban change and the new spatial organization, termed as the "city region". Instead, a redistribution of economic activities and population among the different parts of growing city regions in the process of adaptation to the global economic system may lead to the shrinkage of other parts. What is more, as highlighted throughout the paper, the spatial changes on the way to growing internationalization and globalization have resulted in a complex spatial pattern in which growth, concentration and dispersion exist alongside shrinkage. This implies that shrinkage in growing city regions cannot be simply interpreted as a result of suburbanization and urban sprawl. This new spatial configuration has been the result of urban economic restructuring, characterized by the redistribution of economic activities at a scale larger than the metropolitan scale to respond to the new dynamics of global restructuring. In this sense the characteristics of the newly emerging city regions have been more complex, and the dynamics behind shrinkage in different parts of the city regions deserve further attention.

This point is also important since in the majority of cases the process of urban shrinkage is further intensified by government policies and strategies owing to the difficulty in identifying shrinkage in a pattern of growth. In such cases, the shrinking parts are embedded in growing regions, and the coexistence of urban growth and shrinkage make the shrinking parts less noticeable. As such, different from cities that are losing population as a whole, the issues of housing vacancy, oversupply of infrastructure and cuts in municipal budgets are not so relevant, and there is a tendency to restructure older built-up areas in parts of the inner city (Grossmann et al., 2008). As a result of these factors, shrinkage is most of the time overlooked by policy-makers. The study of urban shrinkage in the Izmir City Region also highlights the role of government policies and strategies in the shrinkage of the metropolitan core. We have argued that this resulting pattern is shaped by the complex interaction of the redistribution of economic activities within the city region in the process of adapting to pressures of globalization and the failure of public policies to understand these local dynamics. This highlights the danger of conceptualizing urban shrinkage as being due to the failure of cities to adapt to globalization, and reveals a need to take into account the influence of public policies and strategies when attempting to understand the processes of urban shrinkage.

It should be noted, however, that urban policies have a critical impact on the evolution of the metropolitan core. In the context of globalization, metropolitan core areas are prone to change, thanks to the relocation of new and existing economic activities, and in this process local policies may accentuate or mitigate shrinkage in these territories. So far, overambitious policies to expand the metropolitan area have reflected concerns about the promotion of the periphery of the metropolitan area driven by the structural economic changes, the unprecedented impact of which has been urban shrinkage in the metropolitan core, necessitating a change in policies for the city region. This policy viewpoint should 
take local dynamics into consideration when defining policy priorities, one of which should be the future of the metropolitan core.

\section{Acknowledgements}

This paper drives on a bigger research project, which is funded by the Scientific Council of Turkey (TÜBITAK), contract no. COST-SOBAG 109K590, 2010-2013.

\section{Note}

1. The second law differed from the first in that it sought to provide credits not only to housing cooperatives, but also to individuals and producers of construction materials.

\section{References}

Albecker, M.-F. (2011) The restructuring of pericentral spaces in global cities (Paris, New York). Paper presented at the conference on Shrinkage in Europe: causes, effects and policy strategies, Amsterdam, NL, February 16-17. Audirac, I. (2009) Urban shrinkage and fast growth: Two faces of contemporary urbanism, in: K. Pallagst, J. Aber, I. Audirac, E. Cunningham-Sabot, S. Fol, C. Martinez-Fernandez, S. Moraes, H. Mulligan, J. Vargas-Hernandez, T. Wiechmann, T. Wu \& Rich, J. (Eds) The Future of Shrinking Cities: Problems, Patterns and Strategies of Urban Transformation in a Global Context, pp. 69-80 (Center for Global Metropolitan Studies, Institute of Urban and Regional Development and the Shrinking Cities International Research Network), IURD Monographs 2009-1. Available at http://repositories.cdlib.org/iurd/ms/MG2009-01, 69-80 (accessed 20 July 2009).

Audirac, I., Cunningham-Sabot, E., Fol, S. \& Moraes, S. T. (2012) Declining suburbs in Europe and Latin America, International Journal of Urban and Regional Research, 36(2), pp. 226-244.

Ayata, S. (2002) The new middle class and the joys of Suburbia, in: D. Kandioti \& A. Saktanber (Eds) Fragments of Culture-The Everyday of Modern Turkey, pp. 25-42 (London: I.B. Tauris).

Beauregard, R. A. (2003) Voices of Decline, The Postwar Fate of US Cities, 2nd ed. (London: Routledge).

Beauregard, R. A. (2006) When America Became Suburban (Minneapolis, MN: University of Minnesota Press).

Bernt, M. (2009) Partnerships for demolition: The governance of urban renewal in East Germany's shrinking cities, International Journal of Urban and Regional Research, 33(3), pp. 754-769.

Beyer, E. (2005) Postsocialism: Russia, in: P. Oswalt (Ed.) Shrinking Cities Volume 1-International Research, pp. 74-77 (Germany: Hantje Cantz, Ostfildern-Ruit).

Bontje, M. (2004) Facing the challenge of shrinking cities in East Germany: The case of Leipzig, GeoJournal, 61(1), pp. 13-21.

Booth, D. (1987) Regional long waves and urban policy, Urban Studies, 24(6), pp. 447-459.

Booza, J. \& Metzger, K. (2004) On some socio-economic aspects of Detroit, in: P. Oswalt (Ed.) Shrinking Cities. A Project Initiated by the Federal Cultural Foundation, Germany in Cooperation with the Gallery for Contemporary Art Leipzig, Bauhaus Foundation Dessau and the journal Archplus, pp. 44-49, Working Papers, Band III (Detroit). Available at http://www.shrinkingcities.com/fileadmin/shrink/downloads/pdfs/WP-Band_III_Detroit.pdf (accessed 16 August 2010).

Boren, T. \& Gentile, M. (2007) Metropolitan processes in post-communist states: An introduction, Geografiska Annaler Series B: Human Geography, 89(2), pp. 95-110.

Brenner, N. (2000) Building 'Euro-regions': Locational policy and the political geography of neoliberalism in post-unification Germany, European Urban and Regional Studies, 7(4), pp. 317-343.

Buzar, S., Ogden, P., Hall, R., Haase, A., Kabisch, S. \& Steinführer, A. (2007) Splintering urban populations: Emergent landscapes of reurbanisation in four European cities, Urban Studies, 44(4), pp. 651-677.

Couch, C. (2004) City of Change and Challenge: Urban Planning and Regeneration in Liverpool (Aldershot: Ashgate Publishing).

Couch, C., Karecha, J., Nuissl, H. \& Rink, D. (2005) Decline and sprawl: An evolving type of urban development - observed in Liverpool and Leipzig, European Planning Studies, 13(1), pp. 117-136.

Cunningham-Sabot, E. \& Fol, S. (2007) Schrumpfende Städte in Westeuropa: Fallstudien aus Frankreich und Grossbritannien, Berliner Debatte Initial, 18(1), pp. 22-35. 
Cunningham-Sabot, E. \& Fol, S. (2009) Shrinking cities in France and Great Britain: A silent process? in: K. Pallagst, J. Aber, I. Audirac, E. Cunningham-Sabot, S. Fol, C. MArtinez-Fernandez, S. Moraes, H. Mulligan, J. Vargas-Hernandez, T. Wiechmann \& T. Wu. (Eds) The Future of Shrinking Cities Problems, Patterns and Strategies of Urban Transformation in a Global Context, pp. 17-27, Monograph Series (Berkeley, CA: Center for Global Metropolitan Studies, UC Berkeley).

Dieleman, F. M. \& Faludi, A. (1998) Polynucleated metropolitan regions in Northwest Europe: Theme of the special issue, European Planning Studies, 6(4), pp. 365-377.

Eraydın, A., Armatli Köroglu, B., Erkus Öztürk, H. \& Yasar, S. (2008a) Network governance for competitiveness: The role of policy networks in the economic performance of settlements in the Izmir Region, Urban Studies, 45(11), pp. 2291-2321.

Eraydın, A., Türel, A., Uzun, N., Armatl1-Köroğlu, B., Ataöv, A. \& Erkuş-Öztürk, H. (2008b) Kentsel Bölgeler için Yeni Örgütlenme Modelleri and Gelişme Stratejileri: Türkiye’de Yeni Dönemde Ortaya Çıkan Kentsel Bölgelerde Rekabetle Sosyal Bütünleşmeyi Uzlaştıran Çok Katmanlı Yönetişim Modellerinin Geliştirilmesi, SOBAG-COST 105K001, Project report, Ankara.

EU (2007) Urban Audit Web Site. Available at http://www.urbanaudit.org (accessed 20 February 2008).

European Commission (2007) Third Report On Economic And Social Cohesion, Part 1 -Cohesion, Competitiveness, Employment and Growth. Brussells.

Ferrari, E. \& Roberts, J. (2004) Liverpool-changing urban form, in: P. Oswalt (Ed.) Shrinking Cities. A Project Initiated by the Federal Cultural Foundation, Germany in Cooperation with the Gallery for Contemporary Art Leipzig, Bauhaus Foundation Dessau and the journal Archplus, pp. 130-136, Working Papers, Band II (Manchester/Liverpool). Available at http://www.shrinkingcities.com/fileadmin/shrink/downloads/pdfs/ WP-II_Manchester_Liverpool.pdf (accessed 19 August 2010).

Fisher, M. M., Diez, J. R. \& Snickars, F. (2001) Metropolitan Innovation Systems: Theory and Evidence from Three Metropolitan Regions in Europe (Berlin: Springer-Verlag).

Fishman, R. (1987) Bourgeois Utopias: The Rise and Fall of Suburbia (New York: Basic Books).

Fishman, R. (2000) The American metropolis at century's end: Past and future influences, Housing Policy Debate, 11(1), pp. 199-213.

Frey, W. H. (2005) Metro America in the New Century: Metropolitan and Central City Demographic Shifts Since 2000 (Washington, DC: The Brookings Institution), Living Cities Census Series.

Friedrichs, J. (1993) A theory of urban decline: Economy, demography and political elites, Urban Studies, 30(6), pp. 907-917.

Gallagher, J. (2004) Detroit suburbanization, in: P. Oswalt (Ed.) Shrinking Cities, Vol. 1. International Research, pp. 242-257 (Ostfildern-Ruit: Hatje Cantz).

Gordon, C. (2008) Mapping Decline: St. Louis and the Fate of the American City (Philadelphia, PA: University of Pennsylvania Press).

Grant, L. (2006) History broke Liverpool, and it broke my heart, in: P. Oswalt (Ed.) Shrinking Cities, Vol. 1. International Research, pp. 421-431 (Ostfildern-Ruit: Hatje Cantz).

Grossmann, K., Haase, A., Rink, D. \& Steinführer, A. (2008) Urban shrinkage in east central Europe? Benefits and limits of a cross-national transfer of research approaches, in: M. Nowak \& M. Nowosielski (Eds) Declining Cities/Developing Cities: Polish and German Perspectives, pp. 77-99 (Poznan: Instytut Zachodhi).

Haase, D., Holzkamper, A. \& Seppelt, R. (2007) Beyond Growth? Decline of the urban fabric in Eastern Germany, in E. Koomen, J. Stillwell, A. Bakema \& H. J. Scholten. (Eds) Modelling Land-Use Change, pp. 339-353 (Dordrecht, NL: Springer). Available at www.springerlink.com/index/C12584UKP2334855. pdf (accessed 11 August 2009).

Hall, P. (2001) Global city-regions in the twenty first century, in: A. Scott (Ed.) Global City Regions:Trends, Theory, Policy, pp. 59-77 (New York: Oxford University Press).

Hollander, J. B., Pallagst, K. \& Popper, F. J. (2009) Planning Shrinking Cities. Available at http://policy.rutgers. edu/faculty/popper/ShrinkingCities.pdf (accessed 11 August 2009).

Hutton, T. A. (2008) The New Economy of the Inner City: Restructuring, Regeneration and Dislocation in the 21st Century Metropolis (London: Routledge).

Işık, O. (1996) 1980 Sonrasında Türkiye'de Kent ve Kentleşme, in: Cumhuriyet Dönemi Ansiklopedisi, vol. 13, pp. 782-801 (İstanbul: İletişim Yayınları).

Kidd, A. (2006) The rise and decline of Manchester, in: P. Oswalt (Ed.) Shrinking Cities, Vol. 1. International Research, pp. 407-416 (Ostfildern-Ruit: Hatje Cantz).

Kil, W. (2005) Ivanovo: The faces of crisis, in: P. Oswalt (Ed.) Shrinking Cities, Vol. 1. International Research, pp. 502-510 (Ostfildern-Ruit: Hatje Cantz). 
Martinez-Fernandez, C., Audirac, I., Fol, S. \& Cunningham-Sabot, E. (2012a) Shrinking cities: Urban challenges of globalization, International Journal of Urban and Regional Research, 36(2), pp. 213-225.

Martinez-Fernandez, C., Wu, C-T., Schatz, L. K., Taira, N. \& Vargas-Hernandez, J. G. (2012b) The shrinking mining city: Urban dynamics and contested territory, International Journal of Urban and Regional Research, 36(2), pp. 245-260.

Metzger, J. T. (2000) Planned abandonment: The neighborhood life-cycle theory and national urban policy, Housing Policy Debate, 11(1), pp. 7-40.

Müller, B. \& Siedentop, S. (2004) Growth and shrinkage in Germany - trends, perspectives and challenges for spatial planning and environment, German Journal of Urban Studies, 43, pp. 14-32.

Nuissl, H. \& Rink, D. (2005) The 'production' of urban sprawl in eastern Germany as a phenomenon of postsocialist transformation, Cities, 22(2), pp. 123-134.

OECD (2003) Science, Technology and Industry Scoreboard (Paris: OECD).

Oswalt, P. \& Rieniets, T. (2006) P. Oswalt \& T. Rienitz (Eds), Atlas of Shrinking Cities (Ostfildern-Ruit: Hatje Cantz).

Oswalt, P. \& T. Rieniets (2007) Global Context. Shrinking Cities. Available at http://www.shrinkingcities.com/ globaler_kontext.0.html?\&L=1 (accessed 9 March 2010).

Pallagst, K. (2008) Shrinking Cities: Planning Challenges from an International Perspective, in: Kent State University's Cleveland Urban Design Collaborative (Ed.), Cities Growing Smaller, pp. 7-16 (Kent: Kent State University).

Pallagst, K. (2009) Shrinking cities in the United States of America: Three cases, three planning stories, in: K. Pallagst, J. Aber, I. Audirac, E. Cunningham-Sabot, S. Fol, C. MArtinez-Fernandez, S. Moraes, H. Mulligan, J. Vargas-Hernandez, T. Wiechmann \& T. Wu. (Eds) The Future of Shrinking Cities: Problems, Patterns and Strategies of Urban Transformation in a Global Context (Berkeley, CA: Center for Global Metropolitan Studies, UC Berkeley).

Pallagst, K. \& Wiechmann, T. (2005) Shrinking smart? Städtische Schrumpfungsprozesse in den USA, in: N. Gestring et al. (Eds) Jahrbuch StadtRegion 2004/2005 Schwerpunkt Schrumpfende Städte, pp. 105-127 (Wiesbaden: VS Verlag für Sozialwissenschaften).

Pallagst, K, Aber, J., Audirac, I., Cunningham-Sabot, E., Fol, S., MArtinez-Fernandez, C., Moraes, S., Mulligan, H., Vargas-Hernandez, J., Wiechmann, T. \& Wu, T. (Eds) (2009) The Future of Shrinking Cities-Problems, Patterns and Strategies of Urban Transformation in a Global Context, Monograph Series (Berkeley, CA: Center for Global Metropolitan Studies, UC Berkeley).

Puentes, R. \& Warren, D. (2006) One-fifth of America: A Comprehensive Guide to America's First Suburbs, Survey Series, Metropolitan Policy Programme (Washington, DC: The Brookings Institution). Available at http://www.michigansuburbsalliance.org/downloads/inner-ring_suburbs-metropolitan_regions/One_ Fifth_of_the_Nation_Americas_First_Suburbs.pdf (accessed 8 August 2010).

Rieniets, T. (2005) Global shrinkage, in: P. Oswalt (Ed.) Shrinking Cities. Vol I: International Research, pp. 20-34 (Wiesbaden: Hatje Cantz, Ostfildern-Ruit).

Sassen, S. (2001) Global cities and global city regions: A comparison, in: A. J. Scott (Ed.) Global City-Regions: Trends, Theory, Policy, pp. 78-95 (Oxford: Oxford University Press).

Saxenian, A. (1991) The origins and dynamics of production networks in Silicon Valley, Research Policy, 20(5), pp. $423-437$.

Scott, A. (2001a) Global City Regions (New York: Oxford University Press).

Scott, A. J. (2001b) Globalization and the rise of city-regions, European Planning Studies, 9(7), pp. 813-824.

Simmie, J. (2001) Innovative Cities (London: Spon Press).

Sousa, S. (2010) Planning for shrinking cities in Portugal, Unpublished PhD thesis, Faculty of Engineering, University of Oporto.

Stanley, R. (2009) The relative city, in: K. Pallagst, J. Aber, I. Audirac, E. Cunningham-Sabot, S. Fol, C. MArtinez-Fernandez, S. Moraes, H. Mulligan, J. Vargas-Hernandez, T. Wiechmann \& T. Wu. (Eds) The Future of Shrinking Cities - Problems, Patterns and Strategies of Urban Transformation in a Global Context, Monograph Series (Berkeley, CA: Center for Global Metropolitan Studies, UC Berkeley).

Steinfuhrer, A. \& Haase, A. (2007) Demographic change as a future challenge for cities in East Central Europe, Geografiska Annaler Series B: Human Geography, 89(2), pp. 183-195.

Tammaru, T., Kulu, H. \& Kask, I. (2004) Urbanization, suburbanization, and counterurbanization in Estonia, Eurasian Geography and Economics, 45(3), pp. 212-229.

Treivish, A. (2006) Ivanovo long-term socio-economic and urban development, in: P. Oswalt (Ed.) Shrinking Cities: Complete Works 1/Analysis, pp. 11-28 (Aachen: ARCH, Verlag GmbH). 
Turok, I. \& Mykhnenko, V. (2007) The trajectories of European Cities, 1960-2005, Cities, 24(3), pp. $165-182$. UN-HABITAT (2008) State of the World's Cities: Harmonious Cities Report 2008/2009. Available at http:// www.unhabitat.org (accessed 2 March 2009).

Wiechmann, T. (2008) Strategic Flexibility beyond growth and shrinkage, Lessons from Dresden, Germany, in: Kent State University's Cleveland Urban Design Collaborative (Ed.), Cities Growing Smaller, pp. 19-29 (Kent: Kent State University).

Wiechmann, T. \& Pallagst, K. M. (2012) Urban shrinkage in Germany and the USA: A comparison of transformation patterns and local strategies, International Journal of Urban and Regional Research, 36(2), pp. 261-280. 